Nigerian Journal of Technology (NIJOTECH)

Vol. 35, No. 1, January 2016, pp. $60-65$ Copyright@ Faculty of Engineering, University of Nigeria, Nsukka, Print ISSN: 0331-8443, Electronic ISSN: 2467-8821

www.nijotech.com

http://dx.doi.org/10.4314/njt.v35i1.10

\title{
PRODUCTION AND CHARACTERIZATION OF LIQUID DETERGENTS FROM SOME AGRICULTURAL WASTE PRODUCTS
}

\author{
O. S. Azeez ${ }^{1, *}$ and G. S. Abegunde ${ }^{2}$ \\ 1, 2 Department of Chemical Engineering, Federal University of TeChnology, Minna. Niger State NigeRIA \\ E-mail addresses: 1 tosin.azeez@futminna.edu.ng, ${ }^{2}$ gasgbenge@gmail.com
}

\begin{abstract}
The aim of this work is to produce and characterized liquid detergents using potassium hydroxide obtained from waste of agricultural materials. The waste agricultural materials are cocoa pods, maize cobs and plantain peels. This was done by ashing these materials in a furnace at a temperature of $1050^{\circ} \mathrm{C}$ and dissolving the ash in de-ionized water to obtain the corresponding hydroxides. The metallic ions in their ashes were analyzed at different temperatures in order to study the effect of temperature on the yield of potassium ion by using atomic absorption spectrophotometer. The temperatures range is $450^{\circ} \mathrm{C}$ to $1050^{\circ} \mathrm{C}$. The obtained results show that the metallic ions of the ash of these materials increase with increase in temperature. Analysis was carried out on the ashes of these materials to determine the oxide of elements in the samples ashed at $1050^{\circ} \mathrm{C}$ using $\mathrm{X}$-ray fluorescence. The characteristics of the detergents formulated were carried out and compared with those of existing detergents purchased in market. The products were characterized based on the following parameters; percentages of active detergent, free oxide, total oxide, lather volume, phosphate, sodium tripolyphosphate, silica and silicate. Also, pH, viscosity and specific gravity. All the characterized properties of the detergents prepared and those purchased in the market fall within the standard for the detergent production. It was discover that the characteristics of the detergents prepared from waste agricultural materials are better than those detergents purchased in the market.
\end{abstract}

Keywords: Detergents, ashing, temperature, characteristics, hydroxide

\section{INTRODUCTION}

Detergent is in great demands in many countries and the quantity required in any society will depend on the population. Most countries, thus, have a large market for detergent but the quality of the detergent produced still needs to be improved upon. In Nigeria, small scale industries and even, some individuals have also embarked on detergent production. It is however important to ensure that the detergent that will be produced should be of good quality so that it can function properly. Detergent normally supports washing action of water since it takes care of surface tension which acts along the surface of water [1].

Detergent is needed on daily basis for maintaining cleanliness and good health operations such as in laundry, cleaning of toilet and washing .Detergent is more effective in washing than soap due to its ability to wash in all types of water without forming scums that will deposit on material been washed. This makes the products to be of higher demand in the market.
One important ingredient used for the production of detergents is potassium hydroxide. It can either be purchased in the market or produced locally from waste or products of agricultural materials. When these agricultural wastes are ashed, it has been observed they are composed of oxides of potassium and other oxide of some elements [5,9]. On the addition of water to the ash of these waste agricultural materials the oxides of potassium and that of some metals will dissolve in the water to form alkali [3]. Some of the metallic oxides present in these ashes are water soluble; some are partially soluble while some are insoluble in water.

This need for this research is due to the availability of these waste agricultural materials in every part of Nigeria. They can therefore serve as alternative to the imported alkalis if they comprise a high amount of potassium hydroxide. Some agricultural wastes suitable for the extraction of potassium hydroxide from their ash include palm bunch waste, cocoa pods, banana leaves, plantain peels, maize cobs, wood and 
sugar beet wastes [8].This research also seek to reduce cost of alkali production since the cost for the manufacture of potassium hydroxide in a commercial way could be higher than those obtained for detergent production locally. $[7,11]$ stressed the need to convert agricultural waste such as cocoa pod to useful products for detergent production since the ash is rich in potassium hydroxide. Alkali level can be maintained in washing process and also washing machine can be protected against corrosion if certain builders can be adopted in detergent formulation [4]. Zeolite has also been incorporated in detergent formulation since it can absorb some of the calcium ions present in water by ion exchange [10]. Production of potassium hydroxide for the production of liquid detergent will be the main focus of this research. The choice of liquid detergent is due to its preference over powder detergent by consumers due to the convenience in dissolution in water for washing purposes. This makes many detergent manufactures to include the production in their activities [2].Another advantage of this research is the need for the reduction of the disposal of these agricultural wastes to reduce environmental pollution.

The needs for producing quality detergent from locally source alkali require the assessment of the ash as will be demonstrated in this research. This will provide vital information on the presence of heavy metals that can cause hazard to the user and the environment as observed by [6]. The equipments that were employed for the analysis of the ash of these agricultural wastes in this research include atomic absorption spectrophotometer (AAS) and x-ray fluorescence (XRF). The AAS was used for the determination of elemental composition as shown in Table 1 while the XRF was used for the oxide composition as shown in Table 2.

\section{METHODOLOGY}

\subsection{Production of Caustic Potash}

The agricultural materials used for the production of alkali in this research are maize cobs, plantain peels and cocoa pods. 12 kilogram each of dried samples maize cobs, plantain peels and cocoa pods) was weighed, crushed and ashed separately in a furnace at $1050^{\circ} \mathrm{C}$. Thereafter, 900 gram of the ashes were weighed and packed in porous containers separately. The ash was sprayed with little (deionized) water and then stirred thoroughly. One liter of deionized water was measured and transferred into the ashes in the porous container separately to form slurry. A clean plastic container was kept at the lower end of each porous container for the collection of the alkali. The relative density of each liquid (alkali) collected was determined using hydrometer. The liquid was repeatedly poured into each ash in the porous containers until a reading of 1280 is obtained on the hydrometer scale. This value of 1280 is the one recommended by the detergent industry based in Ilorin as the value that correlates with alkali meant for detergent production.

The elemental analysis of the ashes using AAS Model Acusyl 211 was done at various temperatures as shown in Table 1 while Oxides in the Ashes of the Agricultural Wastes Products at $1050^{\circ} \mathrm{C}$ are as shown in XRF Results in Table 2.

\subsection{Production of the Liquid Detergents}

$5 \%$ of carboxyl methyl cellulose, CMC (100 g), 4\% of nitrosol $(80 \mathrm{~g}), 5 \%$ of sodium laureth sulfate, SLS (100g), $4 \%$ of ethylene diamine tetra acetic acid EDTA $(80 \mathrm{~g}), 1.2 \%$ of formaline $(24 \mathrm{~g}), 5 \%$ of magnesium sulphate, $\mathrm{MgSO}_{4}(100 \mathrm{~g}), 0.10 \%$ of brine $(2 \mathrm{~g}), 4 \%$ of zeolite $(80 \mathrm{~g}), 0.1 \%$ of dye $(2 \mathrm{~g})$ and $0.20 \%$ of perfume (4g) were weighed into a reaction vessel. $49 \%$ of deionized water (warmed in a boiler at $\left.70^{\circ} \mathrm{C}\right)(1,060 \mathrm{~g})$ was added to the raw materials in the reaction vessel. It was thoroughly stirred for 10 minutes. The stirred mixture was left for about 24 hours to ensure a proper digestion. $3.40 \%$ of caustic potash, $\mathrm{KOH}(48 \mathrm{~g})$ was added to the mixture in the reaction vessel, and finally with $20 \%$ of sulphonic acid $(400 \mathrm{~g})$. The mixture was thoroughly stirred for proper mixing. The stirring was stopped after the vigorous foaming has stopped. The $\mathrm{pH}$ of the detergent was measured using a $\mathrm{pH}$ meter. This procedure was used for the production of detergent using the ashes of the three agricultural wastes in turn.

\subsection{Characterization of the liquid detergents}

The characteristics of the liquid detergents measured are percentage active detergent, percentage free oxide, $\mathrm{pH}$, lather volume (foaming ability), percentage total oxide, percentage phosphate, percentage sodium tripolyphophate (STPP)., viscosity, percentage silicate and specific gravity. 
Table 1: The Elemental Composition of the Ashes obtained from the Agricultural Wastes at different temperatures as shown from the AAS results.

\begin{tabular}{|c|c|c|c|c|}
\hline $\begin{array}{l}\text { Metallic Ions } \\
(\mathrm{mg} / \mathrm{kg})\end{array}$ & $\begin{array}{c}\text { Temp } \\
\left({ }^{\circ} \mathrm{C}\right)\end{array}$ & $\begin{array}{l}\text { Cocoa } \\
\text { Pods }\end{array}$ & $\begin{array}{l}\text { Maize } \\
\text { Cobs }\end{array}$ & $\begin{array}{l}\text { Plantain } \\
\text { Peels }\end{array}$ \\
\hline \multirow{7}{*}{$\mathrm{Cu}$} & 450 & 0.57 & 0.17 & 0.79 \\
\hline & 550 & 0.72 & 0.19 & 0.82 \\
\hline & 650 & 0.77 & 0.29 & 0.90 \\
\hline & 750 & 0.78 & 0.43 & 0.99 \\
\hline & 850 & 0.79 & 0.49 & 2.57 \\
\hline & 950 & 0.83 & 0.59 & 2.59 \\
\hline & 1050 & 0.84 & 0.59 & 2.60 \\
\hline \multirow{7}{*}{$\mathrm{Pb}$} & 450 & 0.79 & 0.99 & 0.82 \\
\hline & 550 & 0.88 & 1.01 & 0.89 \\
\hline & 650 & 6.84 & 1.26 & 1.91 \\
\hline & 750 & 10.92 & 2.99 & 3.56 \\
\hline & 850 & 11.99 & 3.91 & 4.91 \\
\hline & 950 & 12.54 & 5.88 & 6.86 \\
\hline & 1050 & 12.54 & 5.89 & 6.89 \\
\hline \multirow{7}{*}{$\mathrm{Zn}$} & 450 & 0.67 & 0.90 & 0.97 \\
\hline & 550 & 0.81 & 0.90 & 1.90 \\
\hline & 650 & 9.53 & 1.08 & 6.35 \\
\hline & 750 & 12.57 & 1.18 & 7.77 \\
\hline & 850 & 12.91 & 2.37 & 7.90 \\
\hline & 950 & 14.00 & 2.45 & 8.81 \\
\hline & 1050 & 13.98 & 2.43 & 8.82 \\
\hline \multirow{7}{*}{$\mathrm{Cr}$} & 450 & 0.75 & 4.04 & 1.07 \\
\hline & 550 & 0.95 & 1.87 & 2.94 \\
\hline & 650 & 8.54 & 3.78 & 4.02 \\
\hline & 750 & 10.90 & 3.84 & 5.74 \\
\hline & 850 & 13.48 & 3.92 & 7.89 \\
\hline & 950 & 14.14 & 3.97 & 8.88 \\
\hline & 1050 & 14.18 & 4.05 & 8.97 \\
\hline \multirow{7}{*}{$\mathrm{Na}$} & 450 & 2.35 & 3.05 & 1.98 \\
\hline & 550 & 6.41 & 0.50 & 4.63 \\
\hline & 650 & 6.45 & 2.38 & 4.75 \\
\hline & 750 & 7.29 & 2.46 & 5.89 \\
\hline & 850 & 10.05 & 2.55 & 7.63 \\
\hline & 950 & 13.63 & 2.64 & 9.43 \\
\hline & 1050 & 14.83 & 2.96 & 9.55 \\
\hline \multirow{7}{*}{ K } & 450 & 1.08 & 7.94 & 2.60 \\
\hline & 550 & 3.80 & 0.60 & 5.76 \\
\hline & 650 & 6.46 & 2.82 & 5.93 \\
\hline & 750 & 8.42 & 2.88 & 6.45 \\
\hline & 850 & 10.43 & 4.86 & 7.80 \\
\hline & 950 & 13.95 & 5.82 & 9.80 \\
\hline & 1050 & 14.86 & 6.82 & 10.35 \\
\hline
\end{tabular}

Table 2: The Elemental Oxides in the Ash of the Agricultural Wastes Products at $1050^{\circ} \mathrm{C}$ as Shown in XRF

\begin{tabular}{cccc}
\multicolumn{3}{c}{ Results } \\
\hline Compound & $\begin{array}{c}\text { Cocoa } \\
\text { PodsConc. } \\
\text { Unit } \%\end{array}$ & $\begin{array}{c}\text { Plantain } \\
\text { PeelsConc. Unit }\end{array}$ & $\begin{array}{c}\text { Maize } \\
\text { CobsConc. } \\
\text { Unit } \%\end{array}$ \\
\hline $\mathrm{SiO}_{2}$ & 9.44 & 16.70 & 15.10 \\
$\mathrm{P}_{2} \mathrm{O}_{5}$ & 2.20 & 0.00 & 0.00 \\
$\mathrm{SO}_{3}$ & 1.70 & 1.50 & 1.50 \\
$\mathrm{Cl}$ & 0.913 & 0.953 & 0.962 \\
$\mathrm{~K}_{2} \mathrm{O}$ & 10.50 & 9.71 & 9.32 \\
$\mathrm{CaO}_{\mathrm{TiO}}$ & 68.82 & 66.31 & 66.15 \\
$\mathrm{~V}_{2} \mathrm{O}_{5}$ & 0.69 & 0.56 & 0.70 \\
$\mathrm{Cr}_{2} \mathrm{O}_{3}$ & 0.008 & 0.02 & 0.005 \\
$\mathrm{MnO}$ & 0.025 & 0.00 & 0.00 \\
$\mathrm{Fe}_{2} \mathrm{O}_{3}$ & 0.15 & 0.16 & 0.15 \\
$\mathrm{CuO}_{2 n}$ & 3.10 & 2.33 & 2.76 \\
$\mathrm{ZnO}_{\mathrm{As}} \mathrm{O}_{3}$ & 0.047 & 0.046 & 0.05 \\
$\mathrm{Rb}_{2} \mathrm{O}$ & 0.597 & 0.485 & 0.383 \\
$\mathrm{SrO}_{\mathrm{ZrO}}$ & 0.008 & 0.009 & 0.008 \\
$\mathrm{In}_{2} \mathrm{O}_{3}$ & 0.035 & 0.035 & 0.035 \\
$\mathrm{BaO}_{\mathrm{Eu}_{2} \mathrm{O}_{3}}$ & 0.580 & 0.575 & 0.580 \\
$\mathrm{PbO}$ & 0.19 & 0.19 & 0.20 \\
\hline & 0.00 & 0.00 & 0.50 \\
& 0.05 & 0.67 & 0.66 \\
& & 0.05 & 0.06 \\
& 0.14 & 0.10 & 0.11 \\
\hline
\end{tabular}

Two popular liquid detergents were purchased from the market, the one labeled A was purchased in $\mathrm{Omu}$ Aran market in, Kwara State while the second one labeled B was purchased in a market in Minna, Niger state, Nigeria. These characteristics obtained for the detergents produced from agricultural products in this research were compared with those purchased in the market. All these characteristics are in turn compared with the standard supplied by the Soap and detergent company where this research was carried out. These comparisons are presented in Table 3.

\section{RESULTS AND DISCUSSIONS}

The analysis was performed in Geological Survey Institute of Nigeria, Aliyu Makama Road, Kaduna, Nigeria.

Table 3: Properties of the Liquid Detergents.

\begin{tabular}{llllllll}
\hline S/N & Parameters & Maize Cobs & Cocoa Pods & Plantain Peels & Detergent A & Detergent B & *Standard \\
\hline 1. & Active detergent (\%) & 17.86 & 23.83 & 18.62 & 11.80 & 13.20 & $12 \mathrm{~min}$ \\
2. & Free oxide (\%) & 0.09 & 0.03 & 0.05 & 0.08 & 0.03 & $0.2-0.5$ \\
3. & pH & 7.8 & 7.3 & 7.4 & 7.5 & 7.5 & $7.0-8.0$ \\
4. & Lather volume & 3.281 & 4.218 & 3.411 & 3.162 & 3.844 & $3.0-4.0$ \\
5. & Total oxide (\%) & 0.25 & 0.14 & 0.08 & 0.18 & 0.18 & $0.09-1.0$ \\
6. & Phosphate $\left(\mathrm{P}_{2} \mathrm{O}_{5}\right)$ & 2.20 & 2.20 & 2.30 & 2.25 & 2.25 & $0-2.0$ \\
7. & STPP (P2O5 1.78$)$ & 3.916 & 3.916 & 4.094 & 4.005 & 4.005 & $0-2.0$ \\
8. & Viscosity (cps) & 280 & 1000 & 290 & 920 & 380 & 300 min
\end{tabular}




\begin{tabular}{llllllll}
\hline S/N & Parameters & Maize Cobs & Cocoa Pods & Plantain Peels & Detergent A & Detergent B & *Standard \\
\hline 9. & Silica $\left(\mathrm{S}_{1} \mathrm{O}_{2}\right)$ & 0.01 & 0.01 & 0.01 & Nil & 0.01 & $0-1.0$ \\
10. & Silicate $\left(\mathrm{S}_{1} \mathrm{O}_{3}\right)$ & 0.02 & 0.02 & 0.02 & $\mathrm{Nil}$ & 0.02 & $0-1.5$ \\
11. & Toxicity & Nil & Nil & Nil & Nil & Nil & Nil \\
12. & Specific gravity & 1.015 & 1.208 & 1.012 & 1.13 & 1.06 & $1.03-1.05$ \\
13. & Hardness & NA & NA & NA & Nil & Nil & Nil \\
14. & Perfume level & OK & OK & OK & Ok & Ok & Ok \\
15. & Transparency & OK & OK & OK & Ok & Ok & Ok \\
\hline
\end{tabular}

NA means not available. min means minimum, ${ }^{*}$ Values as supplied by an Ilorin based Soaps and Detergents Industry in Nigeria.

\section{DISCUSSION OF RESULTS}

The result of the analysis of the ashes using atomic absorption spectrophotometer (AAS) as shown in Table 1 shows that the metallic ions concentrations increase with increase in temperature for the three raw materials (maize cobs, cocoa pods and plantain peels). The concentration of potassium ion at each temperature is greater than those of sodium ion concentration except for plantain peels where it is lower at $450^{\circ} \mathrm{C}$. Cocoa pods ash contain the highest concentration of potassium ion, followed by that of plantain peels while the least is that of maize cobs. The ashing of these materials were stopped at $1050^{\circ} \mathrm{C}$ because at $950{ }^{\circ} \mathrm{C}$ and $1050{ }^{\circ} \mathrm{C}$ the concentrations of the ions of $\mathrm{Cu}, \mathrm{Pb}$ and $\mathrm{Zn}$ are constant for both plantain peels and cocoa pods while for maize cobs, the ions of $\mathrm{Cu}, \mathrm{Zn}, \mathrm{Pb}$ and $\mathrm{Cr}$ were approximately constant. Although the concentrations of $\mathrm{Na}$ and $\mathrm{K}$ were still increasing at these two temperatures but a complete ashing was obtained at $1050^{\circ} \mathrm{C}$ for the three samples.

X-ray fluorescence (XRF) was used for the determination of the percentage composition of the oxide of the elements presence in the three samples at $1050^{\circ} \mathrm{C}$. The $\mathrm{K}_{2} \mathrm{O}$ was in highest concentration in the cocoa pods ash with a value of 10.5 percent, next to it is the ash of plantain peels with a value of 9.71 percent while maize cobs ash has the least with a value of 9.32 percent.

Calcium oxide will partially dissolve in water to form calcium hydroxide. The amount of calcium oxide is 68.82 percent with the highest value in cocoa pods ash, plantain peels contains the oxide with 66.31 percent and the least is maize cobs ash with 66.15 percent.

Sulfur trioxide is used by industry for sulfonation (a group that is directly attach to alkyl benzene) in detergents. Cocoa pods ash contains the highest amount of this oxide in it (1.7 percent) plantain peels and maize cobs ashes both contain this oxide in equal amount with a value of 1.5 percent.
Silica aids drying in detergents, it is an oxide of silicon which can be tapped from the soil by the plants. The ash of plantain peels contains 16.7 percent of this oxide with the highest amount among the three samples, 15.1 percent in maize cobs ash and 9.44 percent in cocoa pods ash.

The presence of other metallic oxides besides potassium and sodium at higher concentrations may limit the lather volume of the detergent but could be adapted as thickeners and emulsifiers in greases. $\mathrm{Fe}_{2} \mathrm{O}_{3}$ (3.10 percent in cocoa pods ash, 2.33 percent in plantain peels ash and 2.76 percent in maize cobs ash); ZnO ( 0.597 percent in cocoa pods, 0.485 percent in plantain peels and 0.383 percent in maize cobs); $\mathrm{CuO}$ ( 0.047 percent in cocoa pods, 0.046 percent in plantain peels and 0.50 percent in maize cobs); $\mathrm{V}_{2} \mathrm{O}_{5}$ ( 0.008 percent in cocoa pods ash, 0.02 percent in plantain peels and 0.005 percent in maize cobs ash); $\mathrm{As}_{2} \mathrm{O}_{3}$ (0.008 percent in both cocoa pods and maize cobs ashes while 0.009 percent in plantain peels).

The results of the active detergent titration showed that the detergent produced using the caustic potash from the ash of cocoa pods have the highest percentage active detergent with a value of 23.83 percent. The next to it was the detergent produced using the caustic potash from the ash of plantain peels. Detergent produced using the alkaline obtained from maize cobs ash has the lowest active detergent with a value of 17.86 percent. Comparing these values with the purchased liquid detergents $\mathrm{A}$ and $\mathrm{B}$, the active detergents are 11.80 percent and 13.20 percent respectively. Active detergent is used to measure the activity or detergency of the sample and it is potassium sulphonate in the detergent [2].It is therefore clear that the detergents produced from the agricultural wastes in this research are better in quality than the commercial ones purchased in the market in terms of their active detergents.

Free oxide and total oxide simply mean the unreacted caustic or excess caustic in the detergent. The higher these oxides in a detergent, the lower the quality. This 
is because if these oxides are present in excess, they affect the user's skin as well as the fabric. The analytical results showed that the detergent produced from the caustic potash of cocoa pods has the lowest values of these oxides with 0.02 percent for free oxide and 0.09 percent for the total oxide. The next to it was the detergent produced from the caustic potash of plantain peels with respective values of 0.03percent and 0.11 percent. Maize cobs detergent has the highest values of these oxides with 0.06 percent for free oxide and 0.16percent for the total oxide. The free oxide and total oxide for the detergent $\mathrm{B}$ were 0.03 percent and 0.18 percent respectively while those of detergent $A$ are 0.08percent and 0.18percent respectively.

The $\mathrm{pH}$ analytical results show that the $\mathrm{pH}$ value of the detergent produced from the caustic potash of maize cobs is higher in value with 7.8 due to the unreacted caustic in it than in the other two detergents. The $\mathrm{pH}$ value of the detergent produced from the plantain peels caustic potash has the next value to it with 7.4 and the least $\mathrm{pH}$ value is the detergent produced from caustic potash of cocoa pods with a value of 7.3. The $\mathrm{pH}$ values for both detergents $\mathrm{A}$ and $\mathrm{B}$ are 7.5.

The foaming ability is determined by the lather volume analytical results. It can also be predicted or observed from the active detergent results. The higher the percentage active detergent, the more the foaming of the detergent. The detergent produced from the caustic potash of cocoa pod foamed higher than others with a value of $4.218 \mathrm{~cm}^{3}$, detergent produced from the caustic potash of plantain peel is next to it with a value of $3.411 \mathrm{~cm}^{3}$ while the detergent produced from the maize cobs caustic potash has the lowest lather volume with $3.281 \mathrm{~cm}^{3}$. The lather volumes for the detergent $A$ and detergent $B$ were $3.162 \mathrm{~cm}^{3}$ and $3.844 \mathrm{~cm}^{3}$ respectively.

Phosphate in a detergent helps to break up large particles of dirt into smaller ones and also serves as anti redeposition properties. Detergent produced using plantain peels ash has the highest percentage phosphate with a value of 2.30percent, detergents produced from cocoa pods and maize cobs ashes have the phosphate value of 2.20 percent. The phosphate in detergents A and B were both 2.25 percent.

Sodium tripolyphosphate (STPP) acts as water softener, foam booster and builder in a detergent. It is a function of the amount of phosphate in the detergent. Since the detergent produced from plantain peels ash has the highest amount of phosphate in it, the amount of sodium tripolyphosphate in it was 4.094 percent. Detergents produced from the ashes of cocoa pods and maize cobs were equal with 3.916 percent each. Detergents purchased from the market were both 4.005 percent.

Viscosity gives the flow characteristics of the detergent and how attractive the liquid detergent will be. It should be noted that viscosities taken in Table 3 were at room temperature. Detergent produced from the ash of cocoa pods has the highest viscosity with a value of $1000 \mathrm{cps}$, next to it is the detergent produced from plantain peels ash with a value of $290 \mathrm{cps}$, the least is the detergent produced from the ash of maize cobs with a value of $280 \mathrm{cps}$. Detergent $A$ has a viscous value of $380 \mathrm{cps}$ and detergent $B$ has a viscous value of $920 \mathrm{cps}$.

Silica $\left(\mathrm{SiO}_{2}\right)$ when present in a detergent aids drying of fabrics and even the detergent. The amount of silica present in the three formulated detergents and in detergent $B$ were the same with a value of 0.01 while detergent $A$ has no silica present in it. Silicate $\left(\mathrm{SiO}_{3}\right)$ will avoid the breaking of the reaction, that is, the skeletal frame work of the detergent when present in the detergent. All the three formulated detergents and detergent $B$ have the same amount of silicate in them with a value of 0.02 . Detergent $A$ has no silicate in it.

\section{CONCLUSION}

1. From the analytical results obtained using atomic absorption spectrophotometer, all the three waste agricultural materials are richer in potassium hydroxide at higher temperatures which shows that they can be commercialized industrially for the production of caustic potash.

2. Based on the results obtained by characterization of the detergents, the existing commercial detergents are not of higher quality than the formulated detergents.

3. Given the standard values which should be met by detergents and soaps as supplied by an Ilorin based Soaps and Detergents Industry, in Nigeria, all the three formulated detergents and the existing commercial detergents that are used as reference in this research are within the range of the standard provided by the industry.

4. All the detergents formulated in this research are better in terms of active detergent than the commercial ones used as reference in this research.

5. The detergent obtained from cocoa pod ash is the best of all in terms of viscosity 


\section{REFERENCES}

[1] Anyakoha, W. M. New School Physics for Senior Secondary School, $6^{\text {th }}$ Edition, Africana First Publisher, 2011.

[2] Henrik, L., Svend, G. K., Peter, S., Lene, J., Christian, I.J., Macro, W. Protease and Amylase Stability in the presence of Chelators Used in Laundry Detergent Applications: Correlation between Chelator Properties and Enzyme Stability in Liquid Detergent. Journal of Surfactant Detergent, Volume 15, 2012, pp. $265-276$.

[3] Irvine, F.R. West Africa Crops, Oxford University Press, $3^{\text {rd }}$ Edition, 1965.

[4] Klaus, S. Gerhard, B., Thomas, S., Friedrich, W., Thomas, K. and Thomas, H. Phosphoric acid and Phosphates in Ullman's Encyclopedia of Industrial Chemistry, Wiley-VCH, Weinhem, 2008.

[5] Kuye, A. 0., \& Okorie, C. Factors Affecting the Lixiviation of Palm Bunch Ash as a Source of Alkali for Soap Production. Ife Journal of Technology, Volume 3, Number 2, 1990, pp.33-37.

[6] Olabanji O. I, Oluyemi, E. A \& Ajayi, O.S. Metal Analyses of Ash Derived Alkalis from Banana and
Plantain Peels in Soap Making, African Journal of Biotechnology, Volume 11 Number 99, 2012,pp.16512- 16518.

[7] Onifade, K. R. The Potential Application of Cocoa Pods Husks for the Manufacture of Caustic Potash, Journal of Agricultural Technology, Volume 2 Number 2, 1994,pp. 59-64.

[8] Onyegbado, C. O., Iyagba, E. T. \& Offor, O.J. Solid Soap Production using Plantain Peels Ash as Source of Alkali, Journal of Applied Sciences and Environmental Management, Volume 6 Number 1, 2002,pp. 73-77.

[9] Onyekwere, C. Cassava Peels Ash: An Alternative Source of Alkali in Soap Production, B. Eng Thesis, Department of Chemical Engineering, University of Port Harcourt, 1996.

[10] Osei, Y. A. "New School Chemistry for Senior Secondary Schools", $6^{\text {th }}$ Edition, African First Publishers, 2013.

[11] Yahaya, L. E., Hamzat, R. A., Aroyeun, S. O., \& Odufuwa, M. I. Production of Liquid detergent from the pods of Kola (Cola nitida), Moor Journal of Agricultural Research, 2012. 